\title{
Study of antibacterial, anti-proliferative and pro-apoptotic potential of the cell extracts of endophytic fungi and bacteria isolated from Pajanelia longifolia (Willd.) K. Schuman
}

\author{
Gowthami G A ${ }^{1}$, Subhankar Das ${ }^{1,2}$, Yalpi Karthik ${ }^{1} \&$ Manjula Ishwara Kalyani ${ }^{{ }^{*}}$ \\ ${ }^{1}$ Department of Studies and Research in Microbiology, Mangalore University, Jnana Kaveri, P G Centre, Chikka Aluvara, Kodagu 571 232, \\ Karnataka, India \\ ${ }^{2}$ Biotechnology Unit, Mangalore University, Mangalagangotri 574 199, Mangalore, Karnataka, India \\ *Email: manjuganesh7176@gmail.com
}

ARTICLE HISTORY

Received: 25 January 2021

Accepted: 11 May 2021

Available online: 01 July 2021

KEYWORDS

Pajanelia longifolia

Bacteria

Fungi

Antiproliferation activity

Pro-apoptotic

Antibacterial activity

\section{ABSTRACT}

Endophytes contribute to the synthesis of significant metabolites in symbiotic association with their host plants. On considering the medicinal importance of the prominent tree species Pajanelia longifolia (Willd.) K. Schuman, the study was conducted to isolate and identify the endophytic bacteria and fungi for their bioactivity. The isolation of endophytic bacteria and fungi were performed by surface sterilisation of the stem and leaf samples of $P$. longifolia. The obtained bacterial and fungal endophytic isolates were maintained in nutrient agar and Potato Dextrose Agar (PDA) media and were examined for colony morphology and microscopic appearances with varied biochemical characterisations. Furthermore, both the fungal and bacterial isolates were subjected to solvent extractions to evaluate antibacterial activity. Also, anti-proliferative effects due to apoptotic induction by the endophytic fungal extracts were checked against proliferative yeast cells. Moreover, endophytic bacteria belonging to Enterococcaceae had shown antibacterial activity against Salmonella species. In the present study, fungal species belonging to Cladosporium predominantly found to inhabit as endophytic fungi in the plant samples. Also, this particular fungus among other selected endophytic fungi attributed to causing effective anti-proliferative activity. The endophytic bacteria belonging to Enterococcus and Micrococcus genera showed significant antimicrobial activity against Salmonella typhimurium (ATCC 23564).

\section{Introduction}

Plant-Microbe interaction is known to have crucial biological activities for both the species participating in the association. Endophytic microbe play a vital role in stabilising physiological and biochemical status within the host attributing to the defensive role against invading plant pathogens (1). The role of endophytes and their associations with the medicinal plant contributes significantly to the medicinal properties of the particular plant $(2,3)$. Endophytic microbes have also been isolated from diverse medicinal plants and have showed significant contributions to the treatment for many ailments by metabolite synthesis and the host biosynthesis $(4,5)$. According to the literature, the endophytic microbes protect their host from infectious agents and against any adverse conditions by secreting bioactive secondary metabolites $(6,7)$.

Since time immemorial medicinal plants have played an important role in the treatment of various diseases. Pajanelia longifolia (Willd.) K. Schuman, a deciduous tree belonging to the family of Bignoniaceae, is considered as one of the important plant species among Western Ghat diversity in Karnataka due to its antibacterial and antioxidant properties. The pharmacological importance of this tree is reported in the treatment of skin disorders, the bark extract is used for treating eczema by local tribes in certain regions of Dakshina Kannada district in Karnataka. The scientific interventions have reported antioxidant, hepatoprotective and cytotoxic activity of the plant $(8,9)$. Many important metabolites from the $P$. longifolia, have been isolated and studied over a long time for medicinal properties such as antibacterial, antifungal, anti-tumour, immunosuppressant, anti-parasitic and antiviral, antioxidant and anti-inflammatory $(10,11)$.

The present study focus on isolation of endophytic bacteria and fungi from leaf and stem of $P$. longifolia. The isolated endophytes were examined for the colony morphology, microscopic staining and biochemical characterisations were also determined. 
The Intracellular metabolites were further extracted to check their pharmacological properties such as antimicrobial, anti-proliferative and pro-apoptotic activities. The Ioslates fungal strains were subjected to apoptosis induction as a measure of cell death due to cytotoxicity was analysed in the mutagen transformed cell model after treating with intracellular extracts from endophytic fungi. Furthermore the isolated bacterial endophytic strains showed prominent antibacterial activity against Salmonella typhimurium (ATCC 23564).

\section{Materials and Methods}

\section{Plant collection}

Pajanelia longifolia was collected from Honnahanakodu region of Karnataka $\left(12^{\circ} 37^{\prime} 02.1 " \mathrm{~N}\right.$ $\left.75^{\circ} 51^{\prime} 36.6^{\prime \prime E}\right)$. The healthy mature leaves and stem samples were collected and transferred to the laboratory in sterile bags.

\section{Isolation of Endophytes from Pajanelia longifolia}

The collected plant parts (as shown in Fig. 1) were washed, dried and cut into small segments measuring about $1 \mathrm{~cm}$. The leaf and stem segments were initially surface sterilised using sterile distilled water, subsequently rinsed with $70 \%$ ethanol and $4 \%$ sodium hypochlorite. Successive washing were carried out thrice using sterilised distilled water and dried aseptically. Surface sterilised segments were placed on water agar media containing chloramphenicol (0.1 mg), Nutrient agar media and (Potato Dextrose Agar) PDA media. Each plate was placed with ten segments in equidistance, followed by setting standard bacterial and fungal growth conditions.

\section{Identification of Endophytic Bacteria using Biochemical Characterisation}

The colony morphology and staining characteristics were observed for each of the Endophytic isolates and documented. The isolates were subjected for biochemical characterisations for IMViC tests, carbohydrate utilisation test, hydrogen sulphide test, catalase test and gelatin hydrolysis tests $(12,13)$.

\section{Identification of Endophytic Fungi}

Endophytic fungal cultures were examined for their characteristics such as growth pattern, size, the colouration of the mycelium and other colony morphological features. The morphological observation of the fungal isolates were observed by lactophenol cotton blue staining for spore arrangement and seen under Phase contrast Microscope (Lawrence and Mayo LM-52-3501) (14, 15).

The isolation rate (IR) was calculated using the formula: $\mathrm{IR}=(\mathrm{Ni} / \mathrm{Nt}), \mathrm{Ni}$ : the number of segments yielding the fungal isolates, $\mathrm{Nt}$ : the total number of segments incubated. The colonisation rate (\%) was calculated using the formula: $\mathrm{CR}=(\mathrm{Ni} / \mathrm{Nt}) \times 100(16)$.

\section{Intracellular extraction from endophytic bacteria}

To obtain bacterial biomass, each of the bacterial isolates was grown by inoculating onto Nutrient broth pH 7.0 and incubated at $37^{\circ} \mathrm{C}$ for 48 hours in a shaker incubator (ROTEK Incubator shaker ROSI-2). The bacterial biomass was collected and their intracellular fractions were extracted using phosphate buffer $\mathrm{pH} 7.2$ by crushing the biomass in mortar pestle. The buffer extracted fractions were further centrifuged at $10000 \mathrm{rpm}$ (Remi CRP 30 Plus VCEF-6571/450 LAL) and the culture-free extract was obtained. Protein content was estimated by Lowry's method using BSA as standard (17) where as the Carbohydrate was estimated by DNS method using glucose as standard (18).

\section{Biomass extraction of endophytic fungal isolates}

Endophytic fungal isolates were cultured in PDB medium for ten days at room temperature on a rotary shaker Remi (Model no. RIS-768) (19, 20). After incubation period the broth was filtered using Whatmann filter paper No. 1 the fungal biomass was then collected and homogenized using mortar and

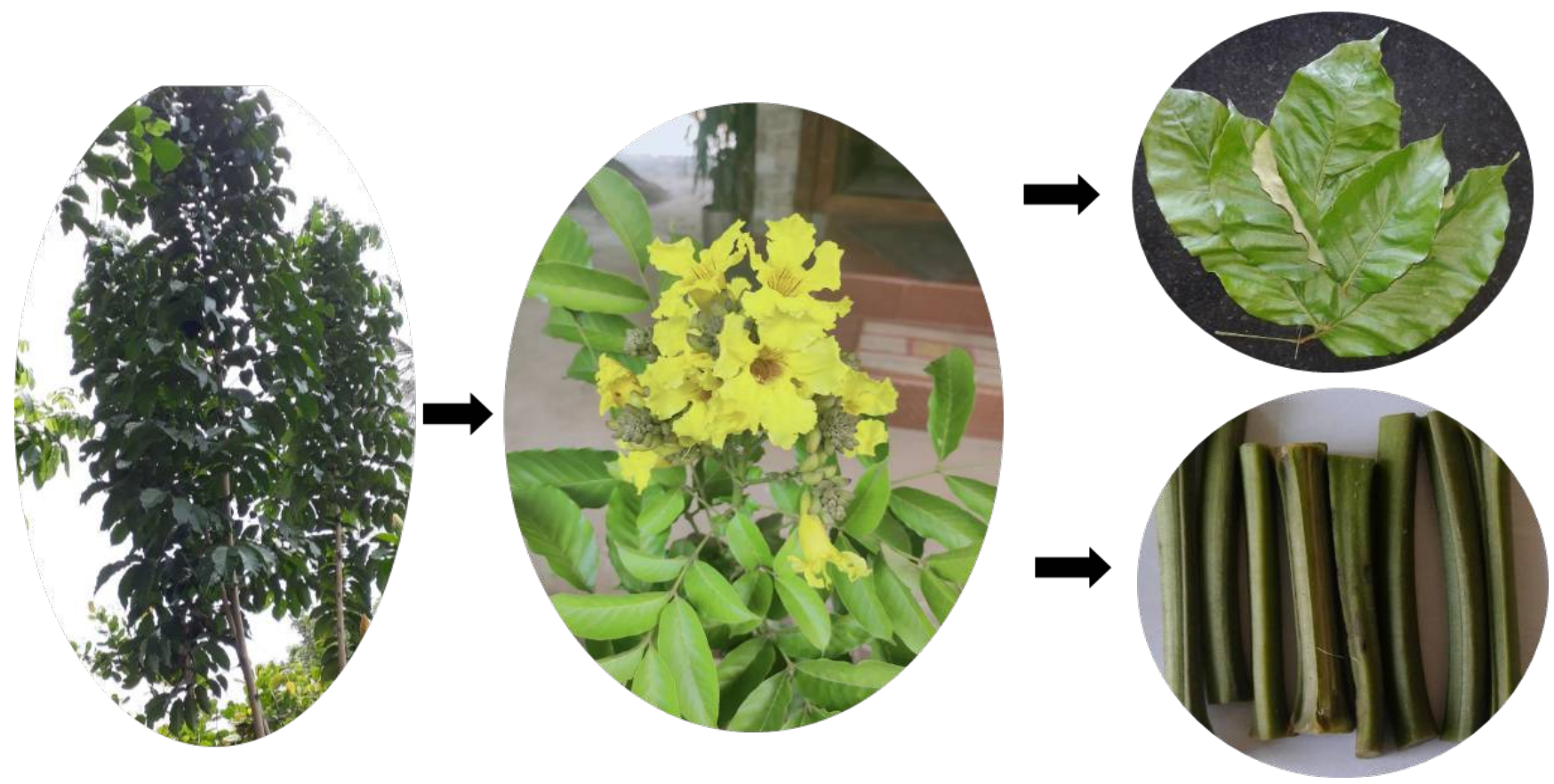

Fig. 1. Leaf and stem of Pajanelia longifolia plant. 
pestle in aseptic conditions in biosafety cabinet (ESCO AC2-4EB class II bio-safety cabinet) by adding equal amount of $0.1 \mathrm{M}$ phosphate buffer $\mathrm{pH}$ 7.2. The intracellular fractions were centrifuged using Remi CRP 30 Plus VCEF-6571/450 LAL at $4000 \mathrm{rpm}$ for 10 min and the supernatant was collected. The culture free extract was obtained for further analysis.

\section{Antibacterial activity of the intracellular extract of endophytic bacterial and fungal isolates}

The obtained endophytic bacterial and fungal extracts were tested for growth inhibition against Escherichia coli (ATCC 8739), Salmonella typhimurium (ATCC 23564), Klebsiella pneumoniae (ATCC 9621), Proteus vulgaris (ATCC 13315) as performed by well diffusion method $(21,22)$.

\section{Anti-proliferative activity of the endophytic fungal extract}

For checking anti-proliferative activity, the intracellular fungal extracts were examined for antiproliferative activity; were treated upon proliferative yeast cells. Saccharomyces cerevisiae were maintained as seed culture in Sabouraud's dextrose broth (SDB) medium and was incubated at $37{ }^{\circ} \mathrm{C}$ for 24 hrs. A standard volume of yeast cells with appropriate cell number from seed culture was transferred to SDB (Glucose 40g/L; Peptone 10g/L) containing phosphate buffer and incubated at $37^{\circ} \mathrm{C}$. The yeast cells were transformed into highly dividing cells by subjecting Ultra Violet irradiation mutagenesis and subsequent growth analysis at an interval of 2 hrs using spectrophotometer (Labman LMSP-UV1900) at wavelength of $670 \mathrm{~nm}$ (23).

\section{Determination of Pro-apoptotic activity of the fungal extract}

The UV-induced proliferative yeast cell system was treated with Endophytic fungal extract at a concentration of $0.01 \mathrm{mg} / \mathrm{ml}$. The rates of cell divisions were analysed in control and treated groups. The proliferative yeast cells after treating with or without Endophytic fungal fractions were stained with trypan blue dye. Cell viability counts were performed for the different time interval of incubation. The treated and untreated, proliferative yeast cells were subjected to staining with Giemsa to analyse morphological changes of a cell undergoing death (24). The cells were then fixed on to slide using methanol and glacial acetic acid solvent mixture; the slides were immersed in Giemsa staining solution for 30-40 min, subsequently, washed with distilled water, air-dried and observed under 40X objective using a phase contrast microscope (Lawrence and Mayo LM-52-3501) (25, 26).

\section{Results}

\section{Isolation and Identification of endophytic} bacteria using Biochemical Characterisation

A total of six endophytic bacterial isolates was isolated from $P$. longifolia, which have showed different colony characteristics as shown in Table 1. Furthermore, the isolated bacterial isolates were subjected to biochemical characterisation as shown in Table 2 with reference to identification mentioned in Bergey's Manual of Determinative Bacteriology, the endophytic bacterial isolates were placed under their taxonomical groups (27).

The endophytic bacteria PL 2(5), PS 1(8), and PS 2(6) were identified as gram-negative cocci and showed positive for Methyl red and positive for glucose, sucrose and lactose fermentation, these isolates were determined belonging to the genus Enterococcus. The gram-positive endophytic cocci, PL 1(3) showed positive Methyl red reaction, catalase test positive and all three carbohydrate utilization tests viz. Glucose, Lactose and Sucrose. The endophytic bacteria were identified as Micrococcus sp.

\section{Morphological Identification of endophytic Fungi}

Eleven fungal isolates have been isolated as shown in Fig. 2 and identified based on their colony and

Table 1. Morphological and staining characterisation of endophytic bacteria

\begin{tabular}{|c|c|c|c|c|c|c|c|c|c|c|c|}
\hline \multirow[b]{2}{*}{ Isolates } & \multicolumn{8}{|c|}{ Colony characters } & \multicolumn{3}{|c|}{ Staining methods } \\
\hline & Shape & Colour & $\begin{array}{c}\text { Puncti } \\
\text { form }\end{array}$ & Raised & Convex & Flat & Globose & $\begin{array}{c}\text { Septate } \\
\text { formation }\end{array}$ & Simple & $\begin{array}{c}\text { Wet } \\
\text { mount }\end{array}$ & $\begin{array}{c}\text { Gram } \\
\text { staining }\end{array}$ \\
\hline PL 2 (5) & Irregular & Cream & + & + & - & - & - & - & Cocci & Cocci & $\begin{array}{c}\text { Gram } \\
\text { negative }\end{array}$ \\
\hline PL 1(3) & Irregular & Cream & - & + & - & - & + & + & Cocci & Cocci & $\begin{array}{c}\text { Gram } \\
\text { Positive }\end{array}$ \\
\hline PS 1 (8) & Entire & Cream & - & + & - & - & - & - & Cocci & Cocci & $\begin{array}{c}\text { Gram } \\
\text { negative }\end{array}$ \\
\hline PS 2 (5) & Entire & $\begin{array}{l}\text { Whitish } \\
\text { cream }\end{array}$ & - & + & + & + & + & + & Cocci & Cocci & $\begin{array}{c}\text { Gram } \\
\text { negative }\end{array}$ \\
\hline PS 2 (6) & Irregular & Cream & + & - & - & + & + & - & Cocci & Cocci & $\begin{array}{c}\text { Gram } \\
\text { negative }\end{array}$ \\
\hline PS 2 (8) & Entire & $\begin{array}{l}\text { Whitish } \\
\text { cream }\end{array}$ & - & - & - & - & - & - & Cocci & Cocci & $\begin{array}{c}\text { Gram } \\
\text { negative }\end{array}$ \\
\hline
\end{tabular}

Table 2. Biochemical properties of endophytic bacteria

\begin{tabular}{|c|c|c|c|c|c|c|c|c|c|}
\hline \multirow{2}{*}{ Isolates } & \multicolumn{3}{|c|}{ IMViC test } & \multicolumn{3}{|c|}{ Carbohydrate } & \multirow{2}{*}{$\mathrm{H}_{2} \mathrm{~S}$} & \multirow{2}{*}{$\begin{array}{c}\text { Gelatin } \\
\text { hydrolysis test }\end{array}$} & \multirow{2}{*}{ Catalase test } \\
\hline & Indole & MR-VP & Citrate utilisation & D & S & $\mathbf{L}$ & & & \\
\hline PL 2 (5) & - & $+/-$ & - & + & + & + & - & - & + \\
\hline PL 1 (3) & - & $+/-$ & - & + & + & + & + & - & + \\
\hline PS 1 (8) & - & $+/-$ & - & + & + & + & - & - & + \\
\hline PS 2 (5) & - & $+/-$ & - & - & + & + & + & - & - \\
\hline PS 2 (6) & - & $+/-$ & - & + & + & + & + & - & + \\
\hline PS 2 (8) & - & $+/-$ & - & - & + & + & - & - & + \\
\hline
\end{tabular}



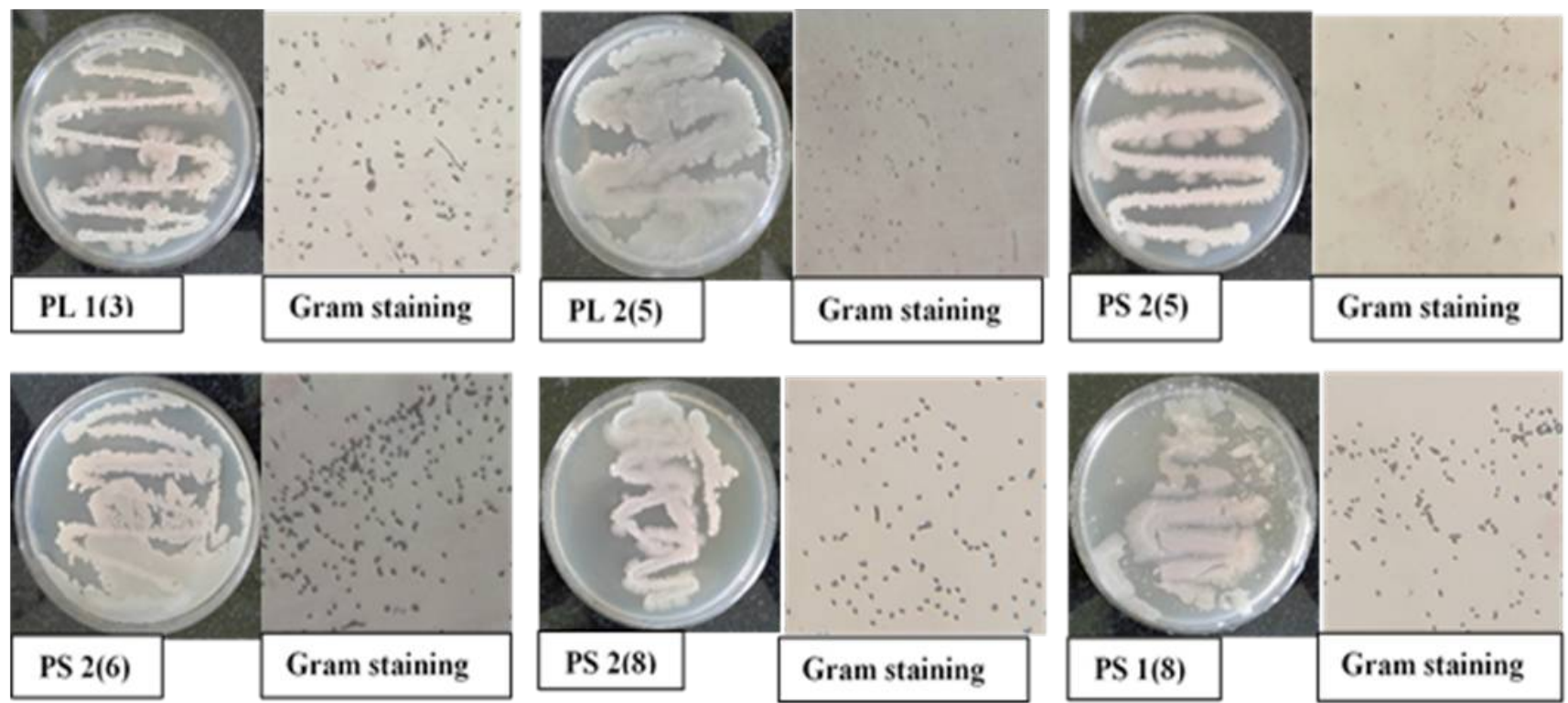

Fig. 2. Morphological and Microscopic view of bacterial endophytes.

microscopic observation with reference to fungi identification manual (28). For every number of segments placed on a growth medium, the isolation and colonisation rates were determined and has been depicted in Table 3.

The spore structure of the fungi identified as Alternaria sp. showed club-shaped septate singly formed spore, as shown in Fig. 4A. As shown in Fig. $4 \mathrm{~B}$, the conidia are arranged on phialides on the conidiophores and thus shows characteristics of the genus Verticillium. Cladosporium sp. and were identified from both the stem and leaf samples with simple conidia and dark spores (Fig. 4C, D, E and G). Fig. 4F identified as Curvularia sp. with concentric colony growth pattern producing curved spores with two to three transverse divisions. Other Endophytic morphospecies were identified from the plant.

Table 3. Isolation rate and colonisation rate of endophytic fungi

\begin{tabular}{lrr}
\hline Plant part & Leaf & \multicolumn{2}{c}{ Stem } \\
\hline Number of segments incubated & 100 & 100 \\
\hline Number of segments yielding endophytic fungi & 4 & 7 \\
\hline Number of isolates & 4 & 7 \\
\hline Isolation rate & 0.04 & 0.07 \\
\hline Colonization rate (\%) & 4 & 7 \\
\hline
\end{tabular}

\section{Antibacterial activity of the intracellular extract of Endophytic bacteria}

Intracellular extract from each of the endophytic bacterial isolates were tested for their antibacterial activity using well diffusion method allowing diffusion of the bacterial metabolite within the preinoculated plates of $E$. coli, S. typhimurium, $K$. pneumoniae and $P$. vulgaris. The plates were then observed for the zone of inhibitions. The isolated Endophytic bacterial metabolites showed no zone of inhibition E. coli, S. typhimurium, K. pneumoniae and $P$. vulgaris. As shown in Fig. 3, the intracellular extractions from Enterococcus sp. PS 1(8) showed significant inhibitions against Salmonella sp. Also, the intracellular extractions from PL 2(5) and Enterococcus PS 2(6) Micrococcus sp. PL 1(3) endophytic bacteria showed inhibitory activity against Salmonella sp.

\section{Antibacterial activity of the intracellular extract of Endophytic Fungal extract}

The species belonging to Cladosporium sp. was predominantly present in $P$. longifolia and have showed inhibitory effect against $P$. vulgaris and $K$. pneumoniae as illustrated in Table 4. Moreover, Curvularia sp. extract showed antibacterial activity against all the selected test pathogens viz., $P$. vulgaris, E. coli, $K$. pneumoniae and $S$. typhimurium. The species of Verticillium extract inhibited the growth of $S$. typhimurium and E. coli.

\section{Anti-proliferative activity of the intracellular extract of endophytic fungal}

Highly proliferative yeast cell (UV treated) when incubated along with intracellular extract of endophytic fungus, Cladosporium sp. and Fusarium $\mathrm{sp}$. induced cytotoxic anti-proliferative effect out of eleven isolates as shown in Fig. 5.

Due to the influence of fungal extract the morphological change occurred in the cell has been noted down at different interval of time depicting the initiation of the cell death within the highly proliferative yeast cell system. Furthermore, the cell counting was carried by the tryphan blue dye exclusion method and it was clear that after 6 to $8 \mathrm{hr}$ incubation, the extracts induced a cytotoxic effect against the proliferative yeast cells.

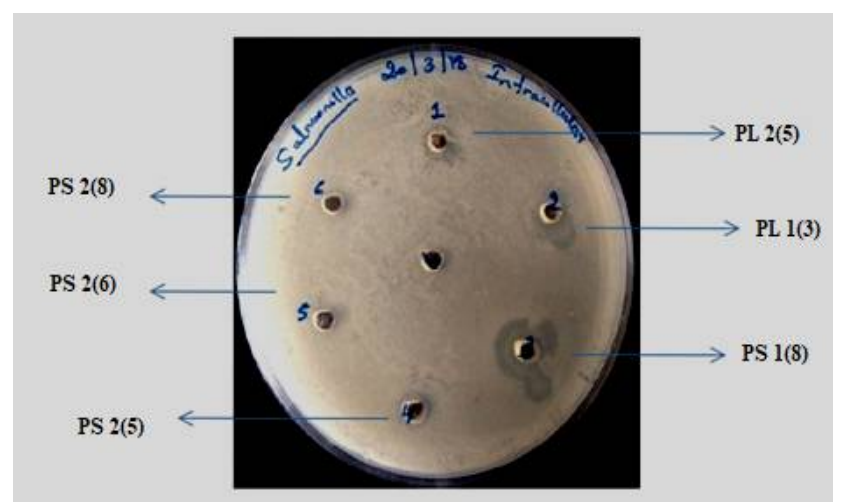

Fig. 3. Intracellular metabolites from endophytic bacteria showing growth inhibition against Salmonella typhimurium (ATCC 23564). 


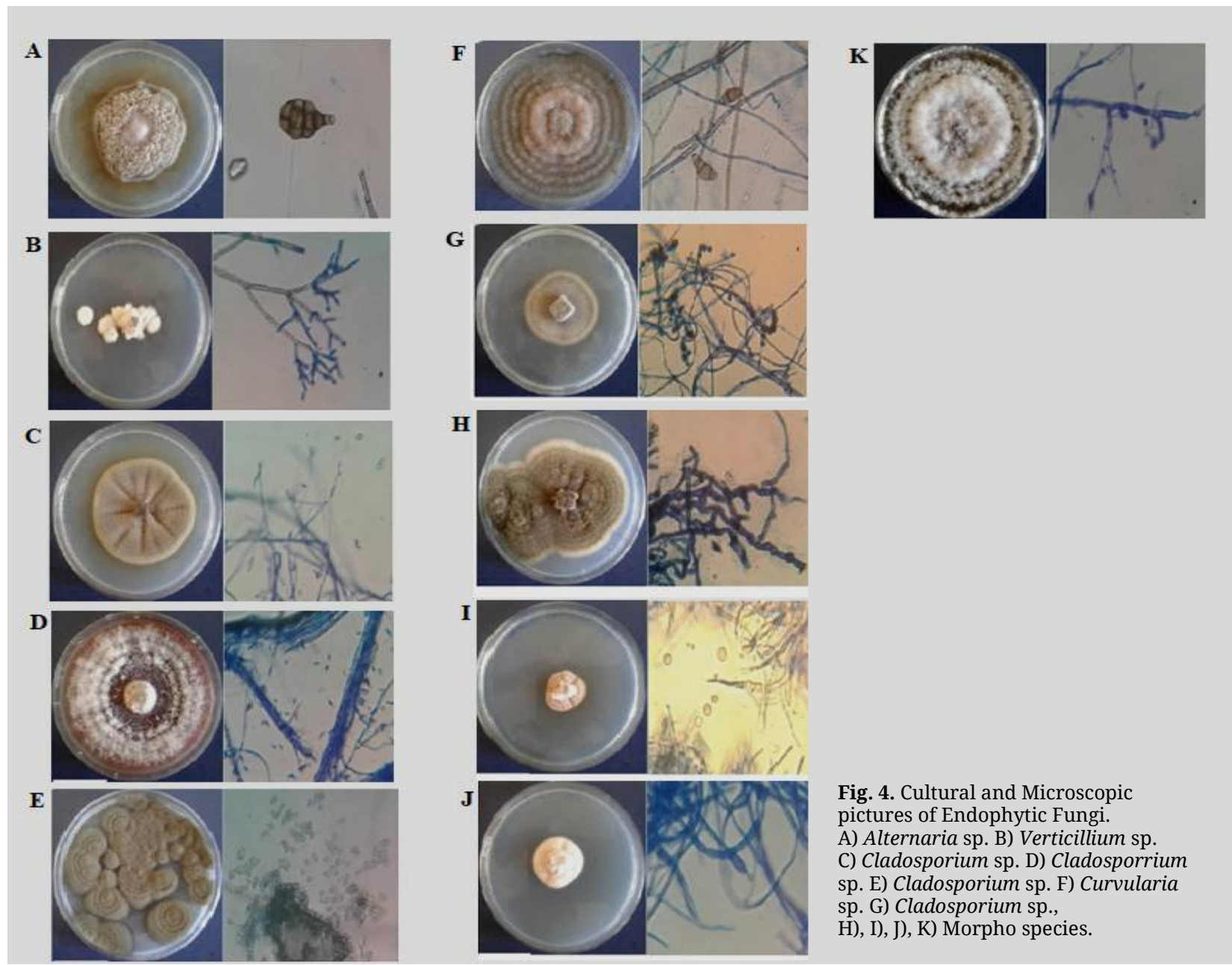

Pro-apoptotic effect of intracellular endophytic fungal extract

The intracellular fungal extract of Cladosporium sp. and Fusarium sp. showed pro-apoptotic effect (Fig. 6). The fungal extract treated yeast cells were stained with Giemsa stain the Yeast cell showed the characteristic morphology of cells undergoing cell death. The characteristic features of chromatin condensation, membrane blebbing and apoptotic bodies are the changes that occur during programmed cell death when treated with the fungal extract.

These results of anti-proliferative and Proapoptotic induction activity from $P$. longifolia fungal endophytes provide substantial information for their detailed analysis of various cancer cell lines and their possible mechanism involved in pharmacological and therapeutic applications.

\section{Discussion}

In the present research we have successfully isolated different bacterial as well as fungal species from $P$. longifolia. The intracellular extract of the isolated endophytic strains showed inhibitory activity against pathogenic bacterial strains and have further induced apoptosis in UV mutated yeast cells. The endophytic bacteria belonging to Enterococci and Micrococci species were isolated from the $P$. longifolia plant that showed effective antibacterial activity against the $K$. pneumoniae, $S$.

Table 4. Antimicrobial activity of the endophytic fungal extracts against bacterial pathogen

\begin{tabular}{|c|c|c|c|c|}
\hline \multirow{2}{*}{ Endophytic fungal isolates } & \multicolumn{4}{|c|}{ Antibacterial Activity } \\
\hline & E. coli & Proteus sp. & Salmonella sp. & Klebsiella sp. \\
\hline Alternaria sp. & - & + & - & - \\
\hline Cladosporium sp. & - & + & - & + \\
\hline Cladosporium sp. & - & + & - & - \\
\hline Cladosporium sp. & - & + & - & - \\
\hline Curvularia sp. & + & + & + & + \\
\hline Fusarium sp. & - & - & - & + \\
\hline Verticillium sp. & + & - & + & - \\
\hline Morpho species 1 & - & + & - & + \\
\hline Morpho species 2 & - & + & - & + \\
\hline Morpho species 3 & + & - & + & - \\
\hline Morpho species 4 & + & + & + & + \\
\hline
\end{tabular}

*(-) Negative, (+) Positive 


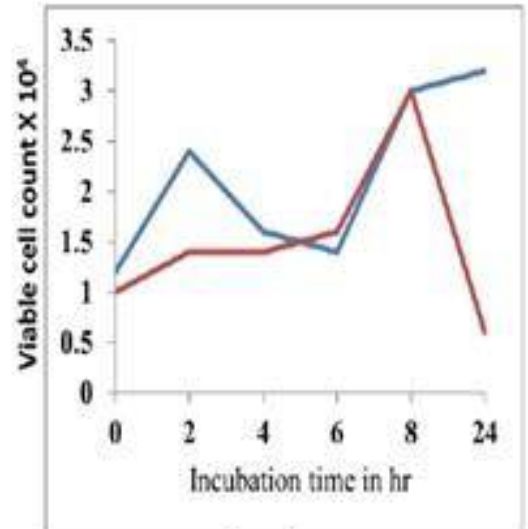

Fusarium sp

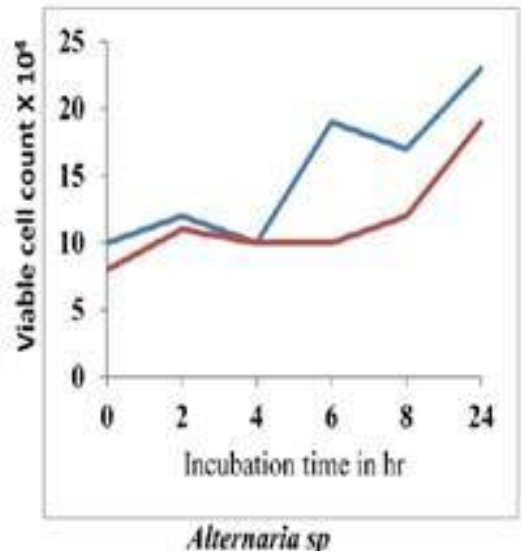

Alternariasp
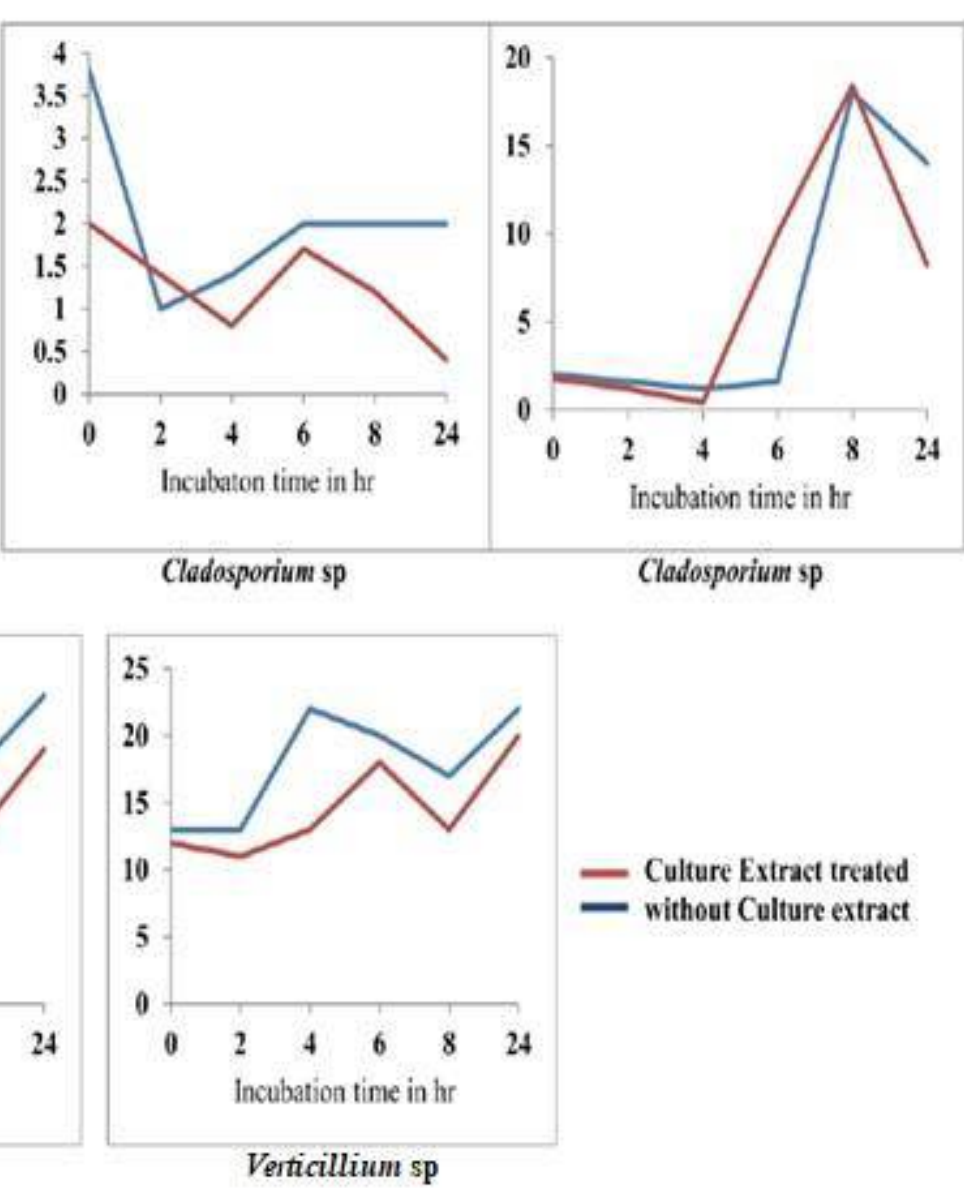

Fig. 5. Anti-proliferative effect of the endophytic fungal extracts on UV induced proliferating yeast cell line.

typhimurium and E. coli bacterial pathogens. This was achieved by performing well diffusion method. Similar reports have showed antibacterial activity against $S$. typhi, $S$. flexneri, $S$. typhi and $S$. marcescens,, Klebsiella sp., E coli, Staphylococcus aureus and Streptoococcus sp. by solvent extracts of leaves of $P$. longifolia $(29,30)$. The present study substantiate, significant metabolite contribution from the endophytic bacterial and fungal strain may play a major role thus complementing along with the plant extracts for pharmacological efficacy (31). Furthermore, the endophytic fungi belonging to the Ascomycota division such as Alternaria sp., Fusarium sp., Cladosporium sp., Verticillium sp., Curvularia sp. and morpho species were identified from the plant. The genera, Cladosporium was predominantly isolated compared to other fungal species thus illustrating that it is one of the prominent fungal endophytes present in the plant (32). Curvularia sp. have exhibited antibacterial activity against $S$. typhimurium, Klebsiella pneumoniae and E. coli, Proteus vulgaris.

Also, the intracellular extract obtained from each of the fungal isolates were analysed for their ability to induce apoptotic cell cytotoxicity in the UV mutated Yeast cell lines. Evidently, the endophytic fungi Cladosporium sp. and Fusarium sp. could demonstrate anti-proliferative activity and was able to induce apoptotic cell death. According to literature, fungal extracts are well capable of inducing apoptosis in tumor cells, staining the cells for morphological observations treated with the intracellular extracts in the treatment groups showed apoptotic morphological features such as membrane blebbing, apoptotic bodies and cell disintegrations (33). The above morphology was not observed in the control groups that were not incorporated with any of the intracellular endophytic fungal extracts. Thus, the present work gives future insight information of the medicinal properties of endophytic bacterial as well as fungal strain whose medicinal properties could further be explored in near future.

\section{Conclusion}

The present study revealed that Pajanelia longifolia (Willd.) K. Schuman harboured a number of endophytic fungi and bacteria. Furthermore, intracellular extractions from both bacterial as well as fungal endophytes exhibited antibacterial activity. The isolated endophytic fungal species belonging to Cladosporium and their occurrences in the plant samples attributed to effective antiproliferative and pro-apoptotic activity in the UV induced yeast cell model. The endophytic bacteria belonging to Enterococcus and Micrococcus genera showed significant antimicrobial activity against Salmonella typhimurium (ATCC 23564). These unexplored endophytes from $P$. longifolia, thus offer a valuable source for identifying intracellular metabolites for pharmacological and therapeutic applications in near future. 


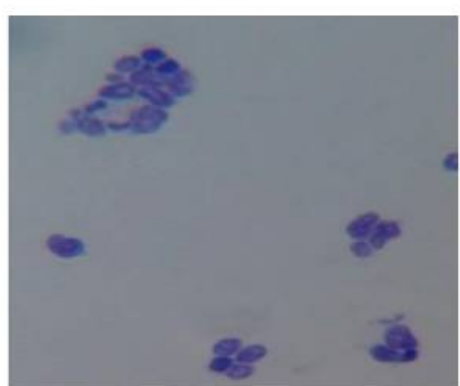

Proliferating yeast cells (-Endophyte fungal extract)

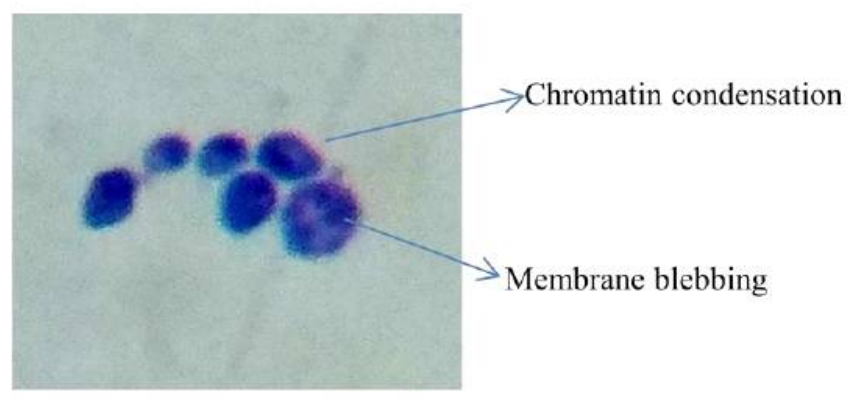

Yeast cell morphology (+ Endophyte fungal extract)

Fig. 6. Chromatin condensation and membrane blebbing in yeast cell line.

\section{Acknowledgements}

The authors thank the Department of Microbiology, Chikka Aluvara, Mangalore University and Molecular Research Laboratory under the Science and Engineering Research Board, DST-Govt. of India for providing the Laboratory facilities to carry out this research work.

\section{Authors' contributions}

GA carried out all the experiments including collection of the plant sample. SD drafted the research article. YK assisted in performing antiproliferative activity and IKM hypothesized the concept of the research work and guided in writing the manuscript.

\section{Conflict of interests}

The authors declare that there is no conflict of interest.

\section{References}

1. Liu H, Carvalhais LC, Crawford M, Singh E, Dennis PG, Pieterse CM, Schenk PM. Inner plant values: diversity, colonization and benefits from endophytic bacteria. Frontiers in Microbiology. 2017 Dec 19;8:2552. https://doi.org/10.3389/fmicb.2017.02552

2. Puri A, Padda KP, Chanway CP. Nitrogen-fixation by endophytic bacteria in agricultural crops: recent advances Nitrogen in agriculture. IntechOpen, London, GBR. 2018 Feb 1:73-94. http://dx.doi.org/10.5772/intechopen.71988

3. Gunatilaka AL. Natural products from plant-associated microorganisms: distribution, structural diversity, bioactivity and implications of their occurrence. Journal of Natural Products. $2006 \quad$ Mar 24;69(3):509-26. https://doi.org/10.1021/np058128n

4. Amaresan N, Jayakumar V, Thajuddin N. Isolation and characterization of endophytic bacteria associated with chilli (Capsicum annuum) grown in coastal agricultural ecosystem. http://nopr.niscair.res.in/handle/123456789/29149

5. Toghueo RM, Zabalgogeazcoa I, de Aldana BV, Boyom FF. Enzymatic activity of endophytic fungi from the medicinal plants Terminalia catappa, Terminalia mantaly and Cananga odorata. South African Journal of Botany. 2017 Mar 1;109:14653. https://doi.org/10.1016/j.sajb.2016.12.021

6. Kannan KP, Madhan Kumar D, Ramya PR, Madhu Nika S, Meenatchi G, Sowmya AN, Bhuvaneswari S. Diversity of endophytic fungi from salt tolerant plants. Int J ChemTech Res. 2014;6:4084-88.

7. Rosenblueth M, Martínez-Romero E. Bacterial endophytes and their interactions with hosts. Molecular Plant-Microbe Interactions. 2006 https://doi.org/10.1094/MPMI-19-0827
8. Padyana S, Zainab A, Ashalatha M, Acharya S. Antioxidant and antibacterial properties of Pajanelia longifolia (Willd.) K. Ann Biol Res. 2011;2:11-18. http://dx.doi.org/10.21474/IJAR01/3894

9. Datta S, Choudhury S, Choudhury MD. Hepatoprotective activity of bark extracts of Pajanelia longifolia (Willd.) $\mathrm{K}$. Schuman against CCl 4 Induced Hepatic Damage in Mice. Drug Invention Today. 2012 Oct 1;4(10):537-39.

10. Saha P, Talukdar AD, Choudhury MD. Antioxidant potential profile of pajanelia longifolia (willd.) K. Schuman; potential new sources of natural anti-oxidant. Asian Journal of Pharmaceutical Clinical Research. 2017 Aug;10:184-88.

11. Nalini MS, Sunayana N, Prakash HS. Endophytic fungal diversity in medicinal plants of Western Ghats, India. International Journal of Biodiversity. 2014 Oct;2014:1-9. http:// dx.doi.org/10.1155/2014/494213

12. Rahman MA, Ahmad T, Mahmud S, Barman NC, Haque MS, Uddin ME, Ahmed R. Isolation, identification and antibiotic sensitivity pattern of Salmonella spp. from locally isolated egg samples. Am J Pure Appl Sci. 2019;1(1):1-11. https://doi.org/10.34104/ajpab.019.019111

13. Abdallah MS, Mustapha T, Gambo A, Ishaq S. Biochemical identification and cultural characterization of some Gramnegative bacteria obtained from fecal/Diarrhoeal samples. Cibtech Journal of Microbiology An Online International Journal. 2016;5:17-24. http://www.cibtech.org/cjm.htm

14. Stone JK, Polishook JD, White JF. Endophytic fungi. Biodiversity of Fungi. Elsevier Academic Press, Burlington. 2004 Jan 1:241-70.

15. Kalyanasundaram I, Nagamuthu J, Muthukumaraswamy S. Antimicrobial activity of endophytic fungi isolated and identified from salt marsh plant in Vellar Estuary. Journal of Microbiology and Antimicrobials. 2015 Feb 28;7(2):13-20. https://doi.org/ 10.5897/JMA2014.0334

16. Liu Z, Chen Y, Lian B, Zhang Z, Zhao Y, Ji Z, Lv Y, Li H. Comparative study on population ecological distribution and extracellular enzyme activities of endophytic fungi in Artemisia annua. Journal of Biosciences and Medicines. 2019 Aug 29;7(08):94-105 http://www.scirp.org/journal/Paperabs.aspx?PaperID=94697

17. Sadananda TS, Govindappa M, Ramachandra YL. In vitro antioxidant activity of lectin from different endophytic fungi of Viscum album L. Journal of Pharmaceutical Research International. 2014 Jan 13:626-43. https://doi.org/10.9734/BJPR/ 2014/6702

18. Robl D, da Silva Delabona P, Mergel CM, Rojas JD, dos Santos Costa P, Pimentel IC, Vicente VA, da Cruz Pradella JG, Padilla G. The capability of endophytic fungi for production of hemicellulases and related enzymes. BMC biotechnology. 2013 Dec;13(1):1-2. http://10.1186/1472-6750-13-94

19. Krishnaswamy A, Barnes N, Lotlikar NP, Damare SR. An improved method for protein extraction from minuscule quantities of fungal biomass. Indian Journal of Microbiology. 2019 Mar 5;59(1):100-04. https://10.1007\%2Fs12088-018-0752-y

20. Klimek-Ochab M, Brzezińska-Rodak M, Żymańczyk-Duda E, Lejczak B, Kafarski P. Comparative study of fungal cell disruption-scope and limitations of the methods. Folia $\begin{array}{llll}\text { Microbiologica. } & 2011 & \text { Sep } & 1 ; 56(5): 469 .\end{array}$ https://doi.org/10.1007/s12223-011-0069-2

21. Özkan G, Kuleaşan H, Çelik S, Göktürk RS, Ünal O. Screening of Turkish endemic Teucrium montbretii subsp. pamphylicum 
extracts for antioxidant and antibacterial activities. Food Control. 2007 May 1;18(5):509-12 https://doi.org/10.1016/j.foodcont.2005.12.009

22. Perez C. Antibiotic assay by agar-well diffusion method. Acta Biol Med Exp. 1990;15:113-15.

23. Karthik Y, Kalyani MI, Sheethal KS, Rakshitha D, Bineesha KB. Cytotoxic and antimicrobial activities of microbial proteins from mangrove soil actinomycetes of Mangalore, Dakshina Kannada. Biomedicine. 2020 Nov 11;40(1):59-67. https://doi.org/ 10.51248/.v40i1.104

24. Li RF, Feng YQ, Chen JH, Ge LT, Xiao SY, Zuo XL. Naringenin suppresses K562 human leukemia cell proliferation and ameliorates Adriamycin-induced oxidative damage in polymorphonuclear leukocytes. Experimental and Therapeutic Medicine. 2015 Mar 1;9(3):697-706 https://10.3892/etm.2015.2185

25. Vanderheyde N, Aksoy E, Amraoui Z, Vandenabeele P, Goldman M, Willems F. Tumoricidal activity of monocytederived dendritic cells: evidence for a caspase-8-dependent, Fas-associated death domain-independent mechanism. The Journal of Immunology. 2001 Oct 1;167(7):3565-69. DOI: https:// doi.org/10.4049/jimmunol.167.7.3565

26. Kalyani MI, Lingaraju SM, Salimath BP. A pro-apoptotic 15-kDa protein from Bacopa monnieri activates caspase-3 and downregulates Bcl-2 gene expression in mouse mammary carcinoma cells. Journal of Natural Medicines. 2013 Jan;67(1):123-36. https://10.1007/s11418-012-0661-z

27. Bergey DH, Breed RS, Murray EG, Hitchens AP. Manual of determinative bacteriology. Manual of Determinative Bacteriology. 5th ed. 1939.

28. Deepthi VC, Sumathi S, Faisal M, Elyas KK. Isolation and identification of endophytic fungi with antimicrobial activities from the leaves of Elaeocarpus sphaericus (Gaertn.) K. Schum. and Myristica fragrans Houtt. International. Journal of Pharmaceutical Sciences and Research. 2018 Jul 1;9(7):2783-91. http://dx.doi.org/10.13040/IJPSR.0975-8232.9(7).2783-91

29. Rani R, Sharma D, Chaturvedi M, Yadav JP. Antibacterial activity of twenty different endophytic fungi isolated from
Calotropis procera and time kill assay. Clin Microbiol. 2017;6(3):280. https://doi.org/10.4172/2327-5073.1000280

30. Tong WY, Darah I, Latiffah Z. Antimicrobial activities of endophytic fungal isolates from medicinal herb Orthosiphon stamineus Benth. Journal of Medicinal Plants Research. 2011 Mar 4;5(5):831-36.

31. Tan XM, Zhou YQ, Zhou XL, Xia XH, Wei Y, He LL, Tang HZ, Yu LY. Diversity and bioactive potential of culturable fungal endophytes of Dysosma versipellis; a rare medicinal plant endemic to China. Scientific Reports. 2018 Apr 12;8(1):1-9.

32. Win PM, Matsumura E, Fukuda K. Diversity of tea endophytic fungi: cultivar-and tissue preferences. Appl Ecol Env Res. 2018 Jan 1;16:677-95. http://dx.doi.org/10.15666/aeer/1601_677695

33. Jia C, Zhang J, Yu L, Wang C, Yang Y, Rong X, Xu K, Chu M. Antifungal activity of coumarin against Candida albicans is related to apoptosis. Frontiers in Cellular and Infection Microbiology. 2019 Jan 4;8:445. https://doi.org/10.3389/fcimb.2018.00445

Additional information

Peer review information: Plant Science Today thanks Sectional Editor and the other anonymous reviewers for their contribution to the peer review of this work.

Reprints and permissions information is available at

https://horizonepublishing.com/journals/index.php/PST/open_access_policy

Publisher's Note: Horizon e-Publishing Group remains neutral with regard to jurisdictional claims in published maps and institutional affiliations.

To cite this article: Gowthami G A, Das S, Karthik Y, Manjula I K. Study of antibacterial, anti-proliferative and pro-apoptotic potential of the cell extracts of endophytic fungi and bacteria isolated from Pajanelia longifolia (Willd.) K. Schuman. Plant Science Today. 2021;8(3):501-508. https://doi.org/10.14719/pst.2021.8.3.1104

Plant Science Today, published by Horizon e-Publishing Group, is covered by Scopus, Web of Science, BIOSIS Previews, Clarivate Analytics, etc. See https://horizonepublishing.com/journals/index.php/PST/indexing_abstracting 